Alina Miruć

\title{
TERMINOWOŚĆ ZAŁATWIANIA SPRAW Z ZAKRESU ADMINISTRACJI PUBLICZNEJ
}

\section{Czas a postępowanie administracyjne ${ }^{1}$}

Problematyka czasu wiąże się ściśle z ustalaniem kolejności zdarzeń, jak i trwałości procesów i stanowi zainteresowanie wielu nauk, w tym także prawa. W nauce prawa, na gruncie poszczególnych jego gałęzi występują rozbieżności co do charakteru czasu, a zwłaszcza jego upływu. Zasadniczo uważa się upływ czasu jako kategorię zdarzeń w ścisłym tego słowa znaczeniu lub węziej - zdarzeń prawnych, także procesowych, niebędących działaniami, a występujących niezależnie od woli podmiotów prawa ${ }^{2}$. Należy podkreślić, iż przepisy prawa często z upływem czasu łączą określone skutki prawne, które powstają z mocy samego jego upływu bądź wskutek upływu czasu wraz występującymi elementami faktycznymi. Upływ czasu może więc być samodzielnym bądź też niesamodzielnym zdarzeniem prawnym, choć najczęściej przyjmuje się jego niesamoistny charakter ${ }^{3}$, zwłaszcza w ujęciu procesowym.

Zagadnienie czasu w postępowaniu administracyjnym często jest rozpatrywane na płaszczyźnie formalnej i dotyczy m.in. terminowości załatwiania spraw indywidualnych z zakresu administracji publicznej. Terminy w postępowaniu administracyjnym spełniają ważne funkcje, z których najważniejszą jest dyscyplinowanie przebiegu postępowania i stanowią przede wszystkim realizację zasady szybkości i prostoty postępowania oraz zasady praworządności. Z tychże zasad dla organu wynika obowiązek racjonalnego planowania i prowadzenia czynności możliwie naj-

\footnotetext{
$1 \quad$ M. Kotulska, Czas a postępowanie administracyjne, (w:) Kodyfikacja postępowania administracyjnego. Na 50lecie kpa., red. J. Niczyporuk, Lublin 2010, s. 421-430.

2 A. Wolter, Prawo cywilne. Zarys części ogólnej, Warszawa 1982, s. 106; Z. Resich, Istota procesu cywilnego, Warszawa 1985, s. 89; J. Nowacki, Z. Tabor, Wstęp do prawoznawstwa, Kraków 2000, s. 25.

$3 \quad$ Z.R. Kmiecik, Oświadczenia procesowe stron w ogólnym postępowaniu administracyjnym, Lublin 2008, s. 36; A. Wasilewski, Upływ czasu jako zdarzenie prawne w prawie administracyjnym, PiP 1966, z. 1, s. 58.
} 
mniejszym nakładem kosztów oraz eliminowaniem zbędnych działań procesowych, często niezgodnych z prawem.

Niekiedy bowiem w praktyce administracyjnej każdy dzień zwłoki odsuwa w czasie realizację zasady praworządności i niekiedy udaremnia realizację nakazu prawa, a późniejsze wydanie orzeczenia może być bezprzedmiotowe. Zaś tzw. powolność postępowania uniemożliwia zrealizowanie celu procedury administracyjnej i obciąża zwykle adresata decyzji.

Normy zawarte w art. 35-38 kodeksu postępowania administracyjnego ustanawiają reguły, które w założeniu mają zapobiec przewlekłości postępowania administracyjnego ${ }^{4}$. Postulat szybkości postępowania realizowany jest $\mathrm{w}$ świetle przepisów procesowych $\mathrm{w}$ dwóch istotnych aspektach: po pierwsze k.p.a. określa dla organów administracji publicznej prowadzących sprawy indywidualne z zakresu administracji publicznej konkretne terminy i po drugie, ustanawia system instytucji i sankcji, które mają dyscyplinować organy do załatwiania sprawy w określonych decyzji terminach.

Celem niniejszego opracowania jest ukazanie i analiza: istoty, charakteru prawnego i rodzajów terminów załatwiania spraw, skutków niezałatwienia sprawy w terminie, instytucji i sankcji dyscyplinujących organy prowadzące postępowanie oraz uprawniających stronę postępowania administracyjnego do realizacji jej procesowych uprawnień w świetle k.p.a., wybranego orzecznictwa sądów administracyjnych oraz doktryny prawa administracyjnego.

\section{Pojęcie i rodzaje terminów załatwiania spraw}

K.p.a. posługuje się pojęciem terminu w dwóch znaczeniach: jako terminu dla oznaczenia czasu w ciagu, którego czynność procesowa może lub powinna być dokonana oraz jako terminu, w którym określona czynność ma się odbyć, tj. dla oznaczenia dnia i godziny. Termin może być wprost oznaczony w kodeksie i określany jest wówczas terminem ustawowym albo też może być terminem wyznaczonym przez organ prowadzący postępowanie.

Można przyjąć, iż terminem załatwienia sprawy indywidualnej z zakresu administracji publicznej jest efektywny czas, jakim w świetle obowiązującego prawa dysponuje organ administracji publicznej w celu rozpatrzenia konkretnej sprawy administracyjnej i wydanie rozstrzygnięcia $w$ formie decyzji administracyjnej ${ }^{5}$, do którego nie wlicza się: terminów przewidzianych w przepisach prawa dla dokonania określonych czynności, np. terminu do zajęcia przez inny organ stanowiska w spra-

Ustawa z dnia 14 czerwca 1960 r., tekst jedn. z 2000 r. Dz.U. Nr 91, poz. 1078 z późn.zm., zwana dalej k.p.a.

R. Kędziora, Ogólne postępowanie administracyjne, Warszawa 2008, s. 166. 
wie ${ }^{6}$, okresów zawieszenia postępowania; również okresów opóźnień spowodowanych przez działania strony lub innych uczestników postępowania oraz podaje się, że innych okresów opóźnień powstałych z przyczyn niezależnych od organu prowadzącego postępowanie.

W świetle k.p.a. ustawowy termin załatwienia sprawy uzależniony jest przede wszystkim od stopnia złożoności sprawy Zgodnie z art. 35 § 1 k.p.a. organy administracji publicznej obowiązane są załatwiać sprawy bez zbędnej zwłoki. Załatwienie sprawy wymagającej postępowania wyjaśniającego powinno mieć miejsce nie później niż w ciagu miesiąca, a sprawy szczególnie skomplikowanej - nie później niż w ciągu dwóch miesięcy od dnia wszczęcia postępowania, w postępowaniu odwoławczym zaś - w ciągu miesiąca od dnia otrzymania odwołania ${ }^{7}$. Ważnym elementem tej konstrukcji prawnej jest maksymalny termin załatwienia sprawy (termin ad quem), który jest uzależniony od charakteru sprawy i jawi się albo terminem ustawowym, albo wyznaczonym. Ma charakter instrukcyjny o tyle, o ile jego upływ nie pozbawia organu do rozstrzygnięcia sprawy i wydania decyzji, rodzi bowiem uprawnienia stronie i nie jest terminem instrukcyjnym w czystej postaci.

Zatem sprawy, które nie wymagają przeprowadzenia postępowania wyjaśniającego i dowodowego, a przede wszystkim zbierania dowodów, informacji i wyjaśnień, powinny być - zdaniem ustawodawcy - załatwiane niezwłocznie. Art. 35 $\S 2$ k.p.a. obliguje organy administracji publicznej do niezwłocznego załatwienia sprawy w sytuacji, gdy: wraz z żądaniem wszczęcia postępowania administracyjnego strona przedstawiła wyczerpujący materiał dowodowy, w oparciu o który organ może już orzekać w sprawie; sprawa może zostać rozpatrzona w oparciu o fakty i dowody powszechnie znane oraz fakty i dowody znane organowi z urzędu; sprawa może zostać rozpatrzona w oparciu o fakty i dowody możliwe do ustalenia danych na podstawie danych, którymi dysponuje organ.

W świetle literatury niezwłocznym załatwieniem sprawy jest jej załatwienie w czasie, jaki jest niezbędny w warunkach prawidłowej organizacji pracy organu do rozpatrzenia żądania strony, zapoznania się z dowodami i innymi okolicznościami istotnymi dla rozstrzygnięcia sprawy, sporządzenia niezbędnej dokumentacji i samej decyzji w sprawie oraz wykonania czynności o charakterze kancelaryjno - biurowym (R. Orzechowski). Należy,więc przyjąć za licznymi wypowiedziami w doktrynie, że to nieprecyzyjne pojęcie oznacza konieczność podjęcia rozstrzygnięcia „od ręki”. ${ }^{8}$ Załatwienie sprawy bez zbędnej zwłoki jest generalną wskazów-

$6 \quad$ Przy tym w przypadku zajęcia stanowiska przez organ współdziałający w trybie art. 106 k.p.a. przed upływem przez ustawę terminu, bierze się pod uwagę rzeczywisty okres dokonywania czynności, a nie czas wyznaczony przez k.p.a. lub przepis szczególny administracyjnego prawa administracyjnego.

$7 \quad$ Art. $35 \S 3$ k.p.a.

8 B. Adamiak, J. Borkowski, Polskie postępowanie administracyjne i sądowoadministracyjne, Warszawa 1993, s. 117 . 
ką dotyczącą załatwiania wszystkich spraw indywidualnych z zakresu administracji publicznej w taki sposób, aby załatwić sprawę w terminie jak najkrótszym niż wyznaczone. Sprawy nie powinny być hamowane w ich rozstrzygnięciu i winny być załatwione najlepiej przed upływem terminu, gdyż terminy miesięczne i dwumiesięczne są terminami maksymalnymi9.

Gdy załatwienie sprawy wymaga przeprowadzenia w sprawie postępowania wyjaśniającego czy to w formie rozprawy, czy też tzw. postępowania gabinetowego, sprawa powinna być załatwiona nie później niż w ciągu miesiąca od dnia wszczęcia postępowania administracyjnego. Zaś jeśli sprawa ma charakter szczególnie skomplikowany, a więc jeżeli mają miejsce np. zawiłe okoliczności faktyczne bądź stan prawny jest skomplikowany do ustalenia, to termin jest dłuższy i sprawa szczególnie skomplikowana powinna być załatwiona w terminie nie dłuższym niż dwa miesiące od dnia wszczęcia postępowania w sprawie.

Zdaniem J. Borkowskiego cecha szczególnego skomplikowania sprawy „może wynikać z zawiłości w ustaleniu stanu faktycznego lub stanu prawnego, konieczności dokonywania licznych czynności postępowania dowodowego, gromadzenia rozproszonych danych będących w posiadaniu różnych organów administracyjnych przy braku prawnego obowiązku współdziałania z nimi" ${ }^{10}$. Dodaje także, że brak jest jasnego kryterium wydzielania spraw o charakterze szczególnie skomplikowanym, zaś ich kwalifikowanie ma bez wątpienia charakter ocenny.

To, czy sprawa ma charakter szczególnie skomplikowany czy nie, należy każdorazowo do oceny organu prowadzącego postępowanie administracyjne w konkretnej sprawie, biorąc pod uwagę specyficzne okoliczności jej stanu zarówno faktycznego, jak i prawnego Zakwalifikowanie sprawy jako szczególnie skomplikowanej wywiera istotne skutki procesowe w sprawie, dlatego też organ powinien o dokonanej kwalifikacji powiadomić strony postępowania ${ }^{11}$. Należy też podkreślić, że błędnym działaniem organu administracji publicznej byłoby powoływanie się na fakt, iż określona kategoria spraw ma generalnie charakter skomplikowany i w związku z tym wszystkie sprawy danego rodzaju muszą być kwalifikowane jako szczególnie skomplikowane ${ }^{12}$.

Natomiast w postępowaniu toczącym się przed organem odwoławczym sprawa powinna być załatwiona w świetle k.p.a. w terminie miesiąca od dnia otrzymania odwołania wraz z aktami sprawy przez organ odwoławczy. W myśl przepisów k.p.a. do terminu załatwienia sprawy w postępowaniu odwoławczym nie wlicza się czasu

9 J. Borkowski, J. Jendrośka, B. Orzechowski, A. Zieliński, Kodeks postępowania administracyjnego. Komentarz, Warszawa 1989, s. 128.

10 B. Adamiak, J. Borkowski, Kodeks postępowania administracyjnego. Komentarz, Warszawa 1996, s. 247.

11 R. Hauser, Terminy załatwiania spraw w KPA w doktrynie i orzecznictwie sądowym, RPEiS 1997, nr 1, s. 4

12 R. Kędziora, op, cit., s. 165. 
przeznaczonego przez prawo do dokonania przez organ orzekający w pierwszej instancji z instytucji samokontroli ${ }^{13}$.

Terminy miesięczne i dwumiesięczne to terminy maksymalne - początkowym momentem biegu terminu załatwiania spraw w pierwszej instancji jest dzień wszczęcia postępowania administracyjnego w sprawie. Dlatego też o zwłoce organu w załatwieniu sprawy administracyjnej można mówić tylko w sytuacji, gdy w sprawie tej toczy się już postępowanie, czyli sprawa jest w toku ${ }^{14}$.

Oprócz ustawowych terminów załatwiania spraw k.p.a. przewiduje też terminy wyznaczone przez organ prowadzący postępowanie. Taki w szczególności charakter mają krótsze terminy załatwiania spraw określonych przez organy wyższego stopnia. Skrócenia terminów mogą dokonywać organy wyższego stopnia poprzez określenie rodzajów spraw, które powinny być załatwiane w terminach krótszych niż przewidziane w k.p.a. i ma ono charakter generalny. W przypadku niezałatwienia sprawy w tak określonym terminie skutki prawne są takie same, jak w przypadku niezałatwienia sprawy w terminie ustawowym, co wynika z faktu, że te szczególne terminy określane są na podstawie i w ramach upoważnienia ustawowego. Terminy załatwiania spraw mogą także ustanawiać przepisy prawa materialnego administracyjnego w drodze ustawy. Mogą to być zarówno terminy krótsze, jak i dłuższe, niż przewiduje kodeks. „Długość” terminu uzależniona jest od charakteru i rodzaju sprawy indywidualnej z zakresu administracji publicznej. Takim przykładem moga być sprawy związane ze zwoływaniem zgromadzeń publicznych. ${ }^{15}$

\section{Zwłoka, milczenie i bezczynność organu administracji publicznej a obowiązek sygnalizacji}

Szybkość jako pojęcie w postępowaniu administracyjnym wyznaczają dwie istotne zasady ogólne rządzące postępowaniem administracyjnym: zasada praworządności oraz zasada szybkości i prostoty postępowania administracyjnego, czyli zasada ekonomiki procesowej. Jeśli powyższe zasady nie zostają wzmocnione instytucjonalnie, to nie istnieje możliwość zapobieżenia brakowi aktywności administracyjnej.

K.p.a. nie posługuje się ani pojęciem bezczynności organu, ani też milczenia organu, lecz pojęciem zwłoki (art. 35 i art. $36 \S 1$ k.p.a.). Co do zasady organy administracji publicznej obowiązane są załatwiać sprawy bez zbędnej zwłoki. Nie-

Wyrok NSA z 15 sierpnia 1985 r., III SAB 7/85, OSPiKA 1989, nr 2, poz. 26 z aprobująca glosa J. Borkowskiego.

15 Na podstawie art. 9 ust. 4 ustawy z 5 dnia lipca 1990 r. - Prawo o zgromadzeniach, Dz.U. Nr 51, poz. 297 z póżn. zm., decyzję wydaną w wyniku rozpatrzenia odwołania doręcza się organizatorowi w terminie 3 dni od dnia otrzymania decyzji administracyjnej w sprawie. 
zwłocznego załatwienia wymagają sprawy, które mogą być rozpatrzone w oparciu o dowody przedłożone przez stronę łącznie z żądaniem wszczęcia postępowania lub też w oparciu o fakty i dowody powszechnie znane albo znane organowi z urzędu, przed którym toczy się postępowanie administracyjne, bądź możliwe do ustalenia na podstawie danych, którymi to on rozporządza.

W literaturze i orzecznictwie pojęcie milczenie organu, czy też szerzej milczenie władzy utożsamiane bywa z pojęciem bezczynności organu ${ }^{16}$. Jednakże pojęcia milczenia i bezczynności organu administracji publicznej nie należałoby ze sobą utożsamiać.

Ogólnie możemy powiedzieć, że stan wywołany niezałatwieniem w terminie sprawy indywidualnej z zakresu administracji publicznej nazywamy milczeniem organu. Należy też uściślić, iż milczenie organu ma miejsce nie tylko wówczas, gdy organ nie podjął żadnych czynności, które zmierzałyby do załatwienia sprawy, ale też w sytuacji, gdy podejmuje on czynności, które jednak skutkują zwłoką, albo też mają na celu uchylenie się od załatwienia sprawy zgodnie $\mathrm{z}$ prawem ${ }^{17}$. $\mathrm{Z}$ milczeniem organu mamy do czynienia także wówczas, gdy odmawia się wydania decyzji, a przepisy prawa do załatwienia danej sprawy wymagają właśnie takiej formy ${ }^{18}$. Natomiast w sytuacji, gdy organ wydał decyzję w terminie, lecz nie ustosunkował się do wszystkich żądań wnoszonych przez stronę, to strona na podstawie art. 111 k.p.a. może prosić o uzupełnienie decyzji; jeśli decyzja nie zostanie uzupełniona, będziemy mieć do czynienia właśnie z milczeniem organu ${ }^{19}$.

Aktualne pojęcie „milczenia administracji” określa się jako formę działania administracji publicznej, która ma zastosowanie w sytuacji określonej hipotezą normy materialnoprawnej, w której przejaw woli organu administracji publicznej w postaci jego milczenia wywołuje skutek prawny, zasadniczo pozytywny dla strony postępowania, która znajduje się w konkretnym stanie faktycznym ${ }^{20} \mathrm{i}$ jest instytucją prawa administracyjnego materialnego.

Bezczynność organu administracji publicznej jest zaś instytucją procesową i stanowi dopuszczona przez przepisy prawa materialnego i procesowego prawną formą działania administracji publicznej. W świetle orzecznictwa NSA przyjmuje się, że o bezczynności organu można mówić nie tylko wtedy, gdy w ustalonym prawem terminie organ nie podjął żadnych czynności, do których był zobowiązany, ale także wtedy, gdy prowadził postępowanie w sprawie, lecz nie zakończył postępowa-

Wyrok NSA z dnia 19 lutego 1999 r., IV SAB 153/98, niepubl.

Postanowienie NSA z dnia 13 lipca 1983 r. II SA 593/83, ONSA 1983, nr 2 poz. 55 z glosą K. Korzana, OSPiKA 1988, nr 3, poz. 52.

Wyrok NSA z dnia 14 czerwca 1983 r., SAP/Wr 6/83, GAP 1987, nr 13, s. 47.

Postanowienie NSA z dnia 8 listopada 1995 r. IV SAB 45/95, ONSA 1996, nr 4, poz. 166.

P. Dobosz, Bezczynność administracji publicznej w postępowaniu administracyjnym, (w:) Kodyfikacja postępowania administracyjnego. Na 50-lecie kpa, red. J. Niczyporuk, Lublin 2010, s. 148. W tymże artykule Autor szczegółowo przytacza poglądy doktryny na temat milczenia administracji. 
nia w terminie decyzją administracyjną. Należy także zaznaczyć, iż z bezczynnością będziemy mieli do czynienia również w sytuacji, gdy organ zawiesił postępowanie administracyjne, jeśli nie istniały ku temu kodeksowe przesłanki ${ }^{21}$.

Zaistniałe faktycznie milczenie organu jest bez watpienia stanem niekorzystnym dla strony i zarazem niezgodnym z obowiązującym prawem, powodując skutek procesowy w postaci nałożenia na organ prowadzący postępowanie w sprawie indywidualnej z zakresu administracji publicznej obowiązek tzw. sygnalizacji. Obowiązek sygnalizacji ciąży na organie prowadzącym postępowanie administracyjne bez względu na przyczynę niezałatwienia sprawy w terminie, zarówno wtedy, gdy zwłoka leży po stronie organu, jak również, gdy jest to działanie strony czy innego uczestnika postępowania.

Ów obowiązek realizowany jest poprzez zawiadomienie strony postępowania o niezałatwieniu sprawy w terminie ustawowym. Organ powinien dokonać zawiadomienia niezwłocznie, $\mathrm{z}$ chwilą pojawienia się przyczyny w załatwieniu sprawy, bez zbędnego oczekiwania na upływ terminu ustawowego. K.p.a. nie określa formy prawnej zawiadomienia. W literaturze zasadniczo przyjmuje się, że ze względu na fakt, że czynność wpływa na uprawnienia o charakterze procesowym strony, to powinna mieć formę postanowienia na które nie przysługuje zażalenie ${ }^{22}$. O każdym przypadku niezałatwienia sprawy w terminie określonym w art. 35 k.p.a. organ administracji publicznej obowiązany jest zawiadomić strony, podając przyczyny zwłoki i wskazując nowy termin załatwienia sprawy. Ten sam obowiązek ciąży na organie administracji publicznej również w przypadku zwłoki w załatwieniu sprawy z przyczyn niezależnych od organu ${ }^{23}$.

Należy podkreślić, że omawiane przepisy k.p.a. mają również zastosowanie w ponownym postępowaniu, jakie toczy się przed organem I instancji po uchyleniu decyzji czy postanowienia w trybie postępowania odwoławczego. Przepisy k.p.a. nie określają, jak „długi” powinien być „nowy termin załatwienia sprawy” wyznaczany na podstawie art. $36 \S 1$ k.p.a. Uwzględniając jednakże, iż kpa. przewiduje terminy dzienne, tygodniowe i miesięczne ${ }^{24}$, należałoby przyjąć, że nowy termin załatwienia sprawy powinien być oznaczony w dniach, tygodniach, miesiącach. ${ }^{25}$. W związku z powyższym niedopuszczalne jest wyznaczanie terminu poprzez użycie np. pojęcia „kwartał”, ponieważ k.p.a. nie zna takiego terminu i nie przewiduje sposobu jego obliczania. Zdaniem NSA narusza zasadę szybkości i prostoty, czy-

21 Wyrok NSA z dnia 23 czerwca 1986 r., 12/86, ONSA1986, nr 2, poz. 52.

22 J. Borkowski, (w:) B. Adamiak, J. Borkowski, Kodeks postępowania administracyjnego. Komentarz, Warszawa 1996, s. 250.

23 Art. $36 \S 1$ i 2 k.p.a.

$24 \quad$ Art. 57 § $1-3$ k.p.a.

25 Tylko wtedy, gdy pewien przedział czasu zostanie określony precyzyjnie poprzez wskazanie momentu jego początku lub przynajmniej końca (np. „sprawa powinna zostać załatwiona do dnia 10 marca bieżącego roku”), można mówić o określeniu terminu. 
li zasadę ekonomiki procesowej np. wyznaczenie przez organ dodatkowego nowego terminu załatwienia konkretnej sprawy administracyjnej w terminie roku ${ }^{26}$. Za wadliwe należałoby uznać także wskazanie terminu załatwienia sprawy jako np. „dwóch miesięcy od dnia zgromadzenia całości materiału dowodowego"27 czy odwołania się do pewnego okresu po wejściu w życie aktów wykonawczych do ustawy ${ }^{28}$.

W k.p.a. zabrakło także wskazania kryteriów, jakimi powinien kierować się organ, wyznaczając nowy termin załatwienia konkretnej sprawy. Jednakże wydaje się, że podstawowym kryterium jest realizacja zasady szybkości i prostoty postępowania oraz zasady praworządności.

Terminy określone w art. 35 k.p.a. mają charakter terminów procesowych i ich upływ ani nie pozbawia organu administracji publicznej możliwości orzekania w sprawie, ani też nie powoduje wadliwości wydanej w takim postępowaniu decyzji administracyjnej. Organ będący w zwłoce nie traci również zdolności do załatwienia sprawy, która jest przedmiotem przewlekającego postępowania, nawet jeśli dzieje się to $\mathrm{z}$ winy organu. Jednakże bezskuteczny upływ terminu wywołuje doniosłe skutki o charakterze procesowym. Należy podkreślić, iż zwłoka organów nie może i nie powinna powodować ujemnych skutków dla strony postępowania administracyjnego ${ }^{29}$.

Należy wspomnieć, iż w doktrynie postępowania administracyjnego formułowano poglądy uznające za korzystniejszą dla strony instytucję sygnalizacji od instytucji dewolucji kompetencji ${ }^{30}$. J. Jendrośka uważa, że w praktyce instytucja sygnalizacji jest nieskuteczna i należałoby ją zastąpić fikcją decyzji administracyjnejej. Podobnie stwierdza J. Borkowski, który podkreśla, że cały ciężar zwalczania bezczynności administracji przeniesiono na stronę postępowania, której to służy prawo wniesienia zażalenia do organu wyższego stopnia po zawiadomieniu jej przez organ administracji o uchybieniu terminowi załatwienia sprawy i wyznaczenia terminu nowego ${ }^{32}$. Stanowiska obu profesorów nie podziela G. Łaszczyca ${ }^{33}$, który uznaje, że fikcja decyzji oraz dewolucja kompetencji powodują utratę dla strony postępowania prawa do merytorycznego rozstrzygnięcia sprawy w dwóch instancjach.

Wyrok NSA z dnia 21 czerwca 1996 r., I SAB 28/96, ONSA 1997, nr 2, poz. 97.

Wyrok WSA z dnia 27 czerwca 2006 r., I SAB/Wa 219/05, LEX nr 219343.

Wyrok NSA z dnia 22 grudnia 2000 r., III SAB 75/00, LEX nr 48005.

Wyrok NSA z dnia 26 lutego 2003 r., V SA1131/ 02, OSP 2003, nr 7-8, poz. 93 z glosą aprobującą Ewy Łętowskiej, OSP 2003.

E. Smoktunowicz, Problemy teorii postępowania administracyjnego na tle kodeksu postępowania administracyjnego, „Studia Prawno-Ekonomiczne” 1972, t. 9, s. 6.

J. Jendrośka, Bezczynność administracji, (w:) Państwo prawa, administracja, sądownictwo. Prace dedykowane profesorowi Januszowi Łętowskiemu w 60. rocznicę urodzin, red. A. Łopatka, A. Wróbel, S. Kielewicz, Warszawa 1999, s. 232.

J. Borkowski, Bezczynność w administracji publicznej, „Kontrola Państwowa” 2008, nr 2 (specjalny), s. 48.

G. Łaszczyca, Milczenie organu w świetle kodeksu postępowania administracyjnego, „Państwo i Prawo” 1999, z. 1, s. 55 . 
Terminowość załatwiania spraw z zakresu administracji publicznej

\section{4. Środki dyscyplinujące organy administracji publicznej do terminowego załatwiania spraw z zakresu administracji publicznej}

W świetle obowiązującego prawa do środków dyscyplinujących organy prowadzące postępowanie administracyjne należy zaliczyć: zażalenie strony na niezałatwienie strony w terminie, skargę na bezczynność organu.

Środek w postaci zażalenia na niezałatwienie sprawy w terminie przewidziany w k.p.a. ma charakter szczególny, gdyż przedmiotem zaskarżenia nie jest akt administracyjny w postaci postanowienia organu, lecz jego niedziałanie, milczenie, czyli stan faktyczny i także prawny, który ma miejsce wskutek niezałatwienia sprawy w terminie ${ }^{34}$. Przysługuje zasadniczo w sytuacji, gdy organ administracji publicznej: nie załatwił sprawy w terminie ustawowym i nie dopełnił obowiązku sygnalizacji oraz nie załatwił sprawy w terminie ustawowym, zawiadomił stronę o przyczynach zwłoki i wyznaczył nowy dodatkowy termin, lecz w tym terminie nie załatwił sprawy. Wskazuje się także na inną sytuację dającą możliwość wniesienia zażalenia. Otóż możliwe jest także użycie takiego środka dyscyplinującego, gdy organ nie załatwił sprawy w terminie ustawowym, dokonał sygnalizacji i wyznaczył nowy termin, jednakże strona postępowania np. kwestionuje zasadność wyznaczania terminu lub jej zdaniem wyznaczony termin jest niedogodny ${ }^{35}$.

Należy przede wszystkim stwierdzić, że jest to zażalenie odrębne od przewidzianego w art. 141-144 k.p.a. i nie jest ono wnoszone jako środek zaskarżenia postawienia jako aktu administracyjnego, lecz służy kwestionowaniu przekroczenia maksymalnego terminu załatwienia sprawy bądź stanowi zaskarżenie wykonania postanowienia organu o wyznaczenie dodatkowego terminu załatwienia sprawy. Może być wniesione w każdym czasie, gdy organ pozostaje w zwłoce. Zakres czynności organu, do którego wniesiono zażalenie w tym trybie, jest ściśle określony oraz zostały sprecyzowane procesowe skutki wywołane przez uzasadnione zażalenie $^{36}$.

Zażalenie strona wnosi do organu właściwego do rozpoznania tego zażalenia, czyli organu wyższego stopnia nad organem, który pozostaje w zwłoce, nawet w sytuacji, gdy w danej sprawie przepis szczególny prawa administracyjnego materialnego przewiduje inny organ właściwy do rozpoznania sprawy ${ }^{37}$. Jeśli organ wyższego stopnia uzna zażalenie za zasadne, winien: wyznaczyć dodatkowy termin, wyjaś-

\footnotetext{
34 Do zażalenia nie będą miały zastosowania przepisy art.141-144 kpa., które regulują tryb zaskarżenia w drodze zażalenia wydanych przez organ postanowień w sprawie.

R. Kedziora, op. cit., s.169.

36 J. Borkowski, Glosa do postanowienia NSA z 7 dnia października 1983 r., SA/Lu 172/83, OSP 1985, nr 7-8, poz. 125 , s. 342.

37 Art. 127 § 2 k.p.a., zob: postanowienie NSA z dnia 8 czerwca 2001 r., I SA 2148/00, niepubl.
} 
nić przyczyny zwłoki i ustalić osoby winne w tejże sprawie, zaś $\mathrm{w}$ razie potrzeby zarządzić podjęcie środków zapobiegających naruszaniu terminów w przyszłości, jeśli podobne sytuacje występują, zdaniem organu, zbyt często. Stanowisko organu rozpatrującego zażalenie w świetle orzecznictwa przyjmuje formę postanowienia, choć nie wynika to wprost z k.p.a. ${ }^{38} \mathrm{~W}$ k.p.a. nie znajdujemy także kryterium, na podstawie którego organ uwzględniający zażalenie wyznacza termin dodatkowego załatwienia sprawy, lecz w myśl zasady ekonomiki procesowej, jak też przepisów k.p.a. o terminach załatwiania spraw powinno być załatwione niezwłocznie. K.p.a. nie określa, jak należy postapić w przypadku uznania zażalenia za nieuzasadnione. Należałoby przyjąć pogląd, że w takiej sytuacji organ powinien w formie postanowienia orzec, że zażalenie nie zostało w konkretnej sprawie uwzględnione.

W miarę potrzeby organ wyższego stopnia ma także możliwość podjęcia środków zapobiegających naruszaniu terminów załatwiania spraw w przyszłości, w szczególności, gdy mają miejsce powtarzające się opóźnienia czy też w przypadkach drastycznego przekraczania terminów. Może to działanie polegać m.in. na zmianie organizacji pracy, przekształceniu organizacyjnemu urzędu czy też wprowadzenie środków dyscypliny pracowniczej.

Kolejnym środkiem dyscyplinującym organy w prowadzeniu i załatwianiu spraw indywidualnych z zakresu administracji publicznej jest skarga na bezczynność organu. Warunkiem, i zarazem możliwością wniesienia skargi na bezczynność organu jest wyczerpanie drogi przewidzianej w k.p.a. skarga może być wniesiona bez względu na to, czy stanowisko organu wyższego stopnia uwzględnia zażalenie, czy też uznaje je po prostu za bezzasadne. W sytuacji, gdy uzna je za bezzasadne, strona ma prawo w postępowaniu przed sądem administracyjnym kwestionować takie orzeczenie organu wyższego stopnia ${ }^{39}$. Zatem zawinienie organu lub jego brak nie przesądzają o dopuszczalności skargi na bezczynnośćc ${ }^{40}$. Przesłanką zasadniczą jest bowiem fakt niezałatwienia sprawy w terminie. Celem wniesienia skargi może być wyłącznie uzyskanie wyroku nakazującego wydanego aktu administracyjnego, decyzji lub postanowienia w określonym przez sąd administracyjny terminie $^{41}$. Wniesienie zażalenia w trybie art. $37 \S 1$ k.p.a. jest warunkiem formalnym wystąpienia ze skargą do wojewódzkiego sądu administracyjnego na bezczynność organu ${ }^{42}$.

Ustawodawca w ustawie Prawo o postępowaniu przed sądami administracyjnymi określa pojęcie bezczynności organu i stanowi, że bezczynność organu to nie

Wyrok NSA z dnia 12 kwietnia 2001 r., IV SA1866/00, ONSA 2002, nr 4 poz. 144.

Wyrok NSA z dnia 24 maja 2001 r., IV SA 572/99, ONSA 2002, nr 3, poz. 116; wyrok WSA z 5 sierpnia 2008 r., IV SAB/Wa, 54/08, niepubl. oraz postanowienie WSA we Wrocławiu z 30 czerwca 2008 r, IV SAB/Wr 12/08, niepubl.

Wyrok WSA w Białymstoku z dnia 4 czerwca 2008 r., II SAB/Bk 15/08, niepubl.

Postanowienie WSA w Krakowie z dnia 28 sierpnia 2008 r., II SAB/Kr 58/08, niepubl.

Postanowienie WSA w Krakowie z dnia 21 sierpnia 2008 r., IISAB Kr 60/08, niepubl. 
tylko niewydanie decyzji administracyjnej, ale także niewydanie określonej kategorii postanowień, a ponadto dokonanie zaniechania innych aktów lub czynności z zakresu administracji publicznej dotyczących uprawnień i obowiązków wynikających z przepisów prawa ${ }^{43}$. Zatem niezałatwienie sprawy w terminie $w$ rozumieniu k.p.a. jest jednym z przejawów szeroko rozumianej bezczynności organu, która może stanowić przedmiot skargi do sądu administracyjnego.

Wojewódzki sąd administracyjny w sytuacji, gdy uwzględni skargę strony na bezczynność organu, musi zobowiązać organ do wydania w określonym terminie aktu administracyjnego bądź czynności, a wyznaczony przez wojewódzki sąd administracyjny termin załatwienia sprawy rozpoczyna bieg od dnia doręczenia akt sprawy organowi administracji publicznej ${ }^{44}$.

Jeżeli bezczynności dopuszcza się organ wyższego stopnia, to stronie nie przysługuje prawo wniesienia skargi na bezczynność organu. Powyższe stanowisko wyrażone zostało w m.in. postanowieniu WSA w Gdańsku z dnia 19 sierpnia 2004 r., gdzie stwierdzono, że w przypadku niewydania przez samorządowe kolegium odwoławcze postanowienia nie przysługuje skarga do sądu administracyjnego w trybie przyjętym w art. $37 \S 1$ k.p.a., gdyż postanowienie takie nie kończy postępowania w sprawie i nie rozstrzyga sprawy co do istoty, ani też nie służy na nie zażalenie ${ }^{45}$. Także na podstawie obowiązującego prawa skarga w powyższej sytuacji nie przysługuje.

W. Chróscielewski podkreśla, iż na tle art. 37 § 2 k.p.a. zarysowały się w sądownictwie administracyjnym rozbieżności dotyczące skargi na decyzję ministra ${ }^{46}$. B. Adamiak, jak również J. Zimmermann, uznają zbędność składania zażalenia w trybie art. 37 k.p.a. przed wniesieniem skargi na bezczynność organu ${ }^{47}$. Ich zdaniem zażalenie nie stanowi conditio sine qua non skargi sądowoadministacyjnej na bezczynność organu. W takiej sytuacji bez wattpienia istnieje konieczność doprecyzowania przepisów k.p.a., z uwagi na rozbieżności stanowisk w doktrynie i w judykaturze.

43 Art. $3 \S 2$ pkt 8 w zw. z pkt 1-4 ustawy z dnia 30 sierpnia 2002 r. - Prawo o postępowaniu przed sądami administracyjnymi, Dz.U. Nr 153, poz. 1270 z póżn. zm.

44 Skutki prawne niewykonania przez organ wyroku sądu normuje art. 154 ustawy Prawo o postępowaniu przed sądami administracyjnymi.

$45 \quad$ II SAB/ Gd 90/92 LEX nr 299477.

46 W. Chróscielewski, Wszczęcie postępowania administracyjnego, PiP 2004, z. 3, s. 65.

47 B. Adamiak, Glosa krytyczna do postanowienia NSA z 17 dnia października 1997, IV SAB 31/97, OSP 1998, nr 10, poz.185, gdzie NSA uzależnił dopuszczalność wniesienia skargi na bezczynność od uprzedniego wniesienia zażalenia w trybie k.p.a.; J. Zimmermann, Glosa do wyroku NSA z dnia15 czerwca 1993, IV SA 1639/92, OSP 1995, nr 4, poz. 88. 


\section{Uwagi końcowe}

Obowiązek załatwienia sprawy w rozsądnym terminie wynika z Europejskiej Konwencji o ochronie praw człowieka i podstawowych wolności (art. 6) ${ }^{48}$, a także z Europejskiego Kodeksu Dobrej Administracji przyjętego przez Parlament Europejski 6 września 2001 r. $\left(\right.$ art. 17) ${ }^{49}$. Rozwiązania zawarte w k.p.a. hołdują temu obowiązkowi. Terminy załatwiania spraw z zakresu administracji publicznej zobowiązują organy prowadzące postępowanie administracyjne do dokonania w wyznaczonym czasie czynności przewidzianych w k.p.a. Można rzec, że są środkiem zmierzającym do zakończenia postępowania i wydania orzeczenia w jak najkrótszym czasie. Bez wątpienia jest to jeden z walorów tzw. dobrej administracji.

Rozważania dotyczące terminowości załatwiania spraw indywidualnych z zakresu administracji publicznej zawarte w opracowaniu nie wyczerpują całej skomplikowanej problematyki odnoszącej się do upływu czasu w postępowaniu administracyjnym, odnoszą się jedynie do terminowości załatwiania spraw indywidualnych z zakresu administracji publicznej w świetle k.p.a., wybranego orzecznictwa sądów administracyjnych i doktryny.

Analiza obowiązującego prawa, literatury i orzecznictwa sądów administracyjnych może prowadzić do konstatacji, iż obowiązujące przepisy k.p.a., choć wymagają niekiedy doprecyzowania, zabezpieczają w wystarczający sposób możliwość dochodzenia przez strony postępowania załatwiania spraw w rozsądnych i stosownych terminach, a organy prowadzące sprawy indywidualne z zakresu administracji publicznej dyscyplinują do sprawnych i efektywnych działań.

Dz.U. z 1993 r. Nr 61, poz. 284

J. Świątkiewicz, Europejski Kodeks Dobrej Administracji (tekst i komentarz o zastosowaniu kodeksu w warunkach polskich procedur administracyjnych), Warszawa 2002. 


\section{PUNCTUALITY IN COMPLETING PUBLIC ADMINISTRATION CASES}

SUMMARY

Time in law, in administrative procedure, may be considered on a process plane as an essential question of punctuality in completing public administration cases. Regulations on time limits for completing cases in the Code of Administrative Procedure reflect the principle of swiftness and simplicity of proceedings and the principle of lawfulness. They simultaneously establish rules to prevent from chronicity of administration procedure and are expected to discipline its course.

Reflections in this paper refer to punctuality in completing individual public administration cases in accordance with the Code of Administrative Procedure, judicature and the administration law doctrine. The objective of this paper is to demonstrate the essence and types of time limits on completing cases, effects of failures to complete them in time, institutions and sanctions disciplining the organs carrying out the proceedings (responsibility for so-called signalization, accountability of an organ worker) as well as authorizing a party of the administrative proceeding to carry out their procedural rights (a complaint about the failure to complete a case in time, a complaint about inaction on the part of the organ). 